\title{
OPTIMAL DESIGN FOR COMPOSITE GIRDER UNDER BIAXIAL BENDING
}

\section{Mohamed A. A. EL-Shaer}

Associate Professor, Department of Civil Engineering, Higher

Technological Institute, $10^{\text {th }}$ of Ramadan City

(Received June 30, 2011 Accepted August 2, 2011)

This paper presents an efficient computer-based method for optimal criteria design of composite girder under biaxial bending. The width, depth for concrete slab and steel section are taken as the design variables. The strength constraints for the design are formulated using the finite element method. The method solves composite girders taking into consideration the material non-linearity due to the change in stressstrain curves of steel and concrete, and geometric non-linearity due to the change of the path of the composite girder during deformation. The formulation depends on the principle of Virtual Work. An optimality criteria method is applied to minimize the cost of concrete slab, steel, and form subject to constraints on strength and stiffness. Four full composite girder examples are presented to illustrate the features of the design optimization method.

It is shown that the design method provides an effective iterative optimization strategy that converges in relatively few cycles to a leastcost design of reinforced concrete element satisfying all relevant requirements of the governing design code. The iterative process is insensitive to the selected initial design and converges smoothly to a final design involving concrete slab dimensions and steel section consistent with usual design practice. A complete computer program has been developed to solve the problem of full composite-beams under biaxial bending.

KEYWORDS: Composite girders, Concrete-slab, Finite element, Material and Geometric non Linearities, Incremental loading, Virtual work, Optimization.

\section{INTRODUCTION}

Considerable research can be found in the structural optimization literature that has focused on reinforced concrete structures. Many studies have been concerned with the optimization of cross-section dimensions because of the repeated use of standard reinforced concrete members in prefabricated construction (e.g. Chou 1977, and Friel 1974). Similar studies have considered individual construction elements such as shear walls, retaining walls, plates, and slabs (e.g. Hajek and Frangopol 1991; Rhomberg and Street 1981). Still other optimization studies have accounted for plastic behavior in reinforced concrete frameworks (e.g. Cohn and Mac Rae 1984). In their work, the objective is to achieve minimum structure cost through redistribution of member forces while satisfying all equilibrium, serviceability, and compatibility conditions for the 
structure. Optimum member capacities are determined rather than optimum crosssectional dimensions of individual members. Another type of optimization problem is concerned with the optimal design of the cross sections of reinforced concrete members within the context of the assembled structure. Elastic behavior of the structure is generally assumed, and the width, depth, and steel reinforcement for member's cross sections are taken as the design variables (e.g. Kanagasundaram and Karihaloo 1990). To this point studies concerned with this design problem have used various types of formal mathematical programming (MP) algorithms to conduct the optimization with varying degrees of success.

The present paper is concerned with the latter design optimization problem noted in the foregoing discussion. Specifically, the optimal determination of section dimensions and reinforcement within the context of an assembled reinforced concrete framework under gravity and lateral loads. Such a design problem involves numerous design variables and constraints, even for modest-size structures, which is perhaps the main reason why formal MP optimization techniques have had limited success in achieving a solution for practical frameworks (i.e. because the basis matrix generally reaches a prohibitive size for the numbers of variables and constrains involved for such structures). On the other hand, the optimality criteria method (Venkayya 1989) is readily applied for the solution of large-scale optimization problems involving many design variables and constrains (primarily because the variable values are established one at a time through a recursive procedure).

Moharrami and Grierson 1993 suggested the optimal criteria (O.C.) which were adopted herein as it has the advantage of converging rapidly compared to other methods and achieving good results. Due to the efficiency of the method, it was adopted in several researches, Chun- Man Chan 2001, used the O.C. method for optimum lateral stiffness design of tall steel and concrete building. The method was applied to an 88-storey building in Hong-Kong. Also Chun-Man and Qian Wang 2006 applied the optimal criteria method and presented a formwork example.

Yasir I. Musa, and Manuel A. Diaz, M. 2007 are studys the composite girders consisting of concrete deck on built-up girders are frequently used in bridge construction for their economic advantages. The use of composite girders results in a very economical design. Additional savings can be obtained in design and material costs for some members by automating design approaches based on optimization techniques. The other describes the use of EXCEL Solver to find the minimum weight for a composite trapezoidal box cross section for a two lane bridge. Design aid tables were generated for structural steel Grades 250, 345, 485, and $690 \mathrm{MPa}$, and different spans varying from $3.0-100 \mathrm{~m}$. The search for the minimum cross section used in this research satisfies the 17th Edition of the American Association of State Highway and Transportation Officials Specifications Load Factor Design method.

Multi Science Publishing 2009, are study the structural optimization seeks the selection of design variables to achieve within the limit (constraints) placed on the structural behaviour, geometry or other factors; its goal of optimality defined by the objective function for specified loading conditions. The three basic features design variables, objective function and constraints contrive to form the design problem. There are several mathematical techniques to solve such problems. The polynomial optimization technique is a recently evolved procedure which is concerned with finding the minimum of a polynomial objective function subjected to constraints. A 
structural design problem has been formulated in this manner which enables minimum cost design to be derived rapidly and simply. It deals with the application of Polynomial optimization technique to Reinforced Concrete (R.C.) beam-member design problem. In the present study this technique is used to determine the minimum cost of reinforced concrete members by considering several design variables such as breadth, depth, area of reinforcing steel etc. Since it is difficult for the designer in the office to become familiar with the mathematical computation required, further attempt is made to represent the resulting optimum design expressions in the form of "Nomograms" which will facilitate the work in the design office.

Shan Suo Zheng, Huan Juan Lou, Lei Li, Zhi Qiang Li, Wei Wang 2011are studes the optimization methodology of the steel-concrete composite beam. The objective function is the cost of the composite beams, and the design variables are the geometry parameters, including height and width of the concrete deck, as well as thickness of the steel flange and web. The constraint conditions are main requirements stated in Chinese code for the design of composite beam, reasonable calculating theories and indispensable constructions, as well as some mature and consistent conclusions confirmed by experimental studies. Stiffness reduction coefficient is used to consider the effect of bond-slip between concrete and steel when calculating the beam deformation. The optimization for composite beam under uniform loads is given as a demonstration example finally. The methodology proposed should be useful for obtaining the solution of this kind of optimization problem.

Therefore, this paper gives the details of the method and presents a computerbased program achieving the minimum cost of full composite girders under biaxial bending. The optimum width, depth, and steel section of girder sections are sought, while ensuring that stresses for girder are within acceptable limits. The explicit design optimization problem is first formulated including the corresponding design sensitivity analysis and then the details of the OC method and design optimization procedure are given. Finally, four full composite girders examples are presented to illustrate the features of the design method. Moreover a design formula expressing the minimum cost was deduced by the writer.

\section{CHARACTERISTICS OF COMPOSITE GIRDER SECTION}

The basic assumptions for the analysis of composite girders in the present analysis are there exists a full composite action or (complete bond) between steel and concrete slab, the strain distribution across the section is assumed to be linear (the plane section before bending remains plane after bending), neglected the effect of shear deformations, torsion deformations, shrinkage and creep of concrete.

The stress strain relationships used in the present work for concrete slab and steel are given by El-Shaer 1997.

\section{DESCRIPTION OF THE FULL COMPOSITE GIRDER}

The full composite cross-section studied is shown in Fig. 1 where a force $F_{z}$ is considered to act at eccentricities $\mathrm{e}_{\mathrm{y}}$ and $\mathrm{e}_{\mathrm{x}}$. 


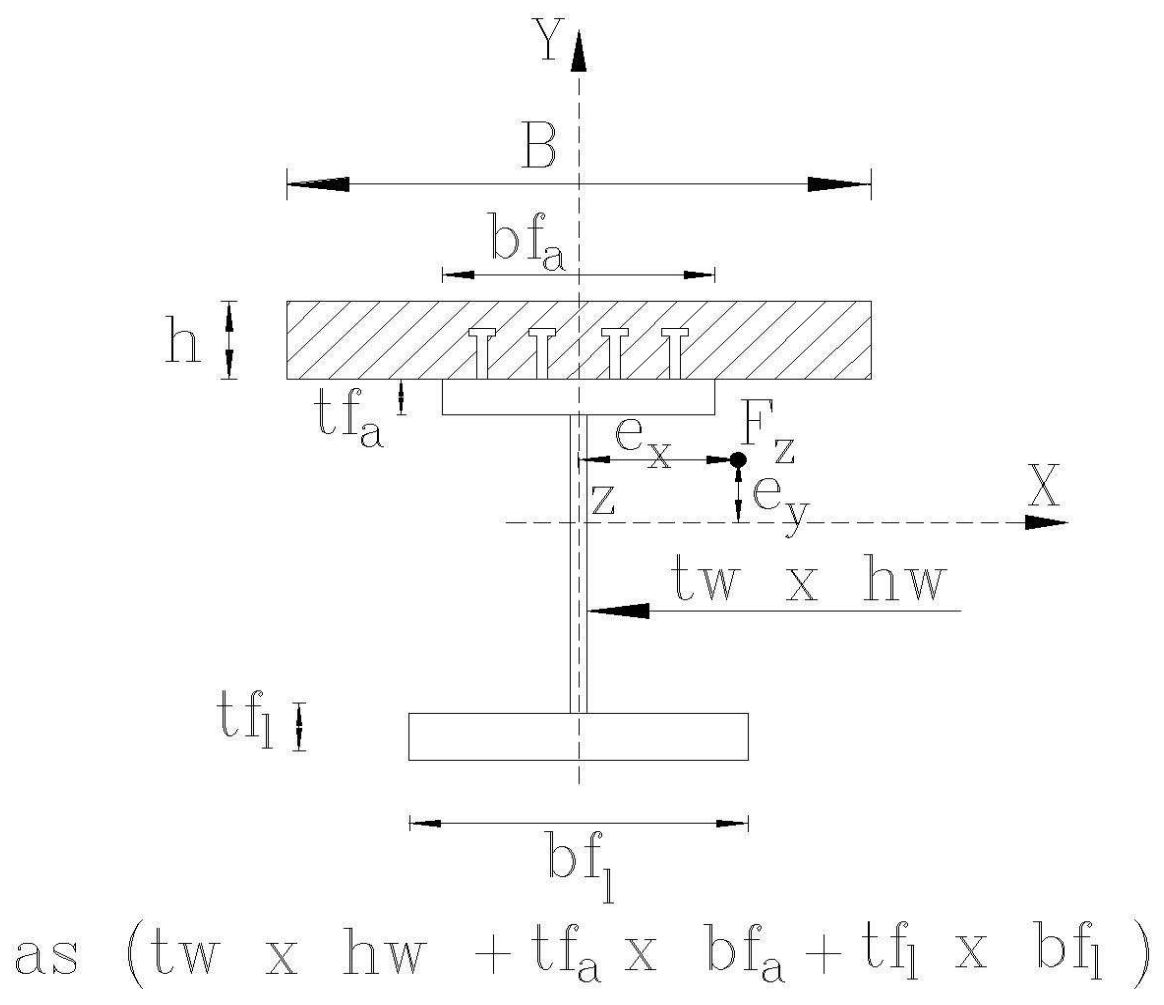

Fig. 1: Geometric Configuration of full composite girder

\section{EXPLICIT DESIGN PROBLEM}

Consider a composite girder whose section for concrete slab is of width $b$, height $h$ and area of steel beam $a_{s}$ the following is the optimization problem.

Minimize:

$\mathrm{Z}=\mathrm{C}_{\mathrm{c}}\left[\mathrm{bh}+\mathrm{a}_{\mathrm{s}}\left(\mathrm{C}_{\mathrm{s}}-1\right)+\mathrm{C}_{\mathrm{f}}(2 \mathrm{~b}+2 \mathrm{~h})\right] \mathrm{L}$

Subject to:-

$\mathrm{F}_{\mathrm{z}}-\mathrm{F}_{\mathrm{zn}} \leq 0$

$\mathrm{M}_{\mathrm{x}}-\mathrm{M}_{\mathrm{xn}} \leq 0$

My- Myn $\leq 0$

$\mathrm{b}_{l} \leq \mathrm{b} \leq \mathrm{b}_{\mathrm{u}} ; \mathrm{h}_{l} \leq \mathrm{h} \leq \mathrm{h}_{\mathrm{u}} ; \mathrm{a}_{\mathrm{s} l} \leq \mathrm{a}_{\mathrm{s}} \leq \mathrm{a}_{\mathrm{su}}$

where

$\mathrm{Z}=$ the cost; $\mathrm{C}_{\mathrm{c}}=\mathrm{Cost}$ of unit volume of concrete; $\mathrm{C}_{\mathrm{s}}=$ ratio of cost of unit volume of steel to the cost of unit volume of concrete; $\mathrm{C}_{\mathrm{f}}=$ ratio of cost of unit area of formwork to cost of unit volume of concrete; $F_{z}, M_{x}$ and $M_{y}=$ internal forces acting on the section concerned; the forces are the axial force, moment about $\mathrm{x}$-axis and moment about $\mathrm{y}$ axis respectively; $\mathrm{F}_{\mathrm{zn}}, \mathrm{M}_{\mathrm{xn}}$ and $\mathrm{M}_{\mathrm{yn}}=$ the corresponding nominal forces.

$\mathrm{b}_{l}, \mathrm{~b}_{\mathrm{u}}, \mathrm{h}_{l}, \mathrm{~h}_{\mathrm{u}}, \mathrm{a}_{\mathrm{s} l}$ and $\mathrm{a}_{\mathrm{su}}$ the lower and upper bounds of $\mathrm{b}, \mathrm{h}$ and $\mathrm{a}_{\mathrm{s}}$. 
Equations ( 2 to 4$)$ can be generalized as:

F- S $\leq 0$

Where

$F=$ the internal forces $\left(F_{z}, M_{x}, M_{y}\right) ; S=$ the strength of the section $\left(F_{z n}, M_{x n}, M_{y n}\right)$.

\section{FORCE AND STRENGTH SENSITIVITIES}

For the purpose of this study, adopt the variable notation:

$\mathrm{x}_{1}=\mathrm{b}, \quad \mathrm{x}_{2}=\mathrm{h}, \quad \mathrm{x}_{3}=\mathrm{a}_{\mathrm{s}}$

Also, adopt a first - order Taylor series expansion to Eqn. (6) to obtain:

$$
F^{0}-S^{0}+\sum_{K=1}^{3}\left(\frac{\partial F^{0}}{\partial X_{K}}-\frac{\partial S^{0}}{\partial X_{K}}\right)\left(X_{K}-X_{K}^{0}\right) \leq 0
$$

Where

superscript zero $(0)=$ known or calculated quantities for the current design ( eg. initial trial design )

$\mathrm{X}_{\mathrm{k}}=$ the design variables $; \mathrm{k}=1,2,3$.

The derivative $\frac{\partial F}{\partial X_{K}}$ is the internal force sensitivity to the design variables $\mathbf{X}_{\mathrm{k}}$.

The derivative $\frac{\partial S}{\partial X_{K}}$ is the strength sensitivity to the design variables $X_{\mathrm{k}}$.

The sensitivities may be evaluated using the finite-difference technique as follows:

Consider the composite girder axial force capacity, $\mathrm{F}_{\mathrm{zn}}$, for the current design variables $\left\{b, h\right.$ and $\left.a_{s}\right\}$ and the six neighboring designs $\left\{b+\delta b, h+\delta h, a_{s}+\delta a_{s}\right\}$ and $\{b-$ $\left.\delta b, h-\delta h, a_{s}-\delta a_{s}\right\}$ where $\delta b, \delta h$ and $\delta a_{s}$ are small specified increments in the design variable. The sensitivities of the composite girder axial force capacity are then found as:

$$
\begin{aligned}
\frac{\partial F_{z n}}{\partial b} & =\frac{F_{z n}(b+\delta b)-F_{z n}(b-\delta b)}{2 \delta b} \\
\frac{\partial F_{z n}}{\partial h} & =\frac{F_{z n}(h+\delta h)-F_{z n}(h-\delta h)}{2 \delta h} \\
\frac{\partial F_{z n}}{\partial a_{s}} & =\frac{F_{z n}\left(a_{s}+\delta a_{s}\right)-F_{z n}\left(a_{s}-\delta a_{s}\right)}{2 \delta a_{s}}
\end{aligned}
$$

The other force and strength sensitivities are determined using the same procedure.

\section{OPTIMALITY CRITERIA METHOD}

The optimization problem can be expressed as minimize:

$\mathbf{Z}=\mathrm{Z}\left(\mathrm{X}_{\mathrm{k}}\right)$

Subject to:

$$
\begin{aligned}
& \mathrm{g}_{\mathrm{j}}\left(\mathrm{X}_{\mathrm{k}}\right) \leq 0 \quad(\mathrm{j}=1, \ldots \ldots \ldots \mathrm{m}) \\
& \mathbf{X}_{\mathrm{k}}{ }^{\mathrm{L}}<\mathbf{X}_{\mathrm{k}}<\mathbf{X}_{\mathrm{k}}{ }^{\mathrm{u}}
\end{aligned}
$$


Where equations (12, 13 and 14) correspond to equations (1, 6 and 5) respectively.

The design optimization problem can be reformulated as the minimization of the Lagrangian function

$$
\mathrm{L}\left(\mathrm{x}_{\mathrm{k}}, \lambda_{\mathrm{j}}\right)=\mathrm{Z}\left(\mathrm{x}_{\mathrm{k}}\right)+\sum_{\mathrm{j}=1}^{\mathrm{m}} \lambda_{\mathrm{j}} \mathrm{g}_{\mathrm{j}}\left(\mathbf{X}_{\mathrm{k}}\right)
$$

Where the Lagrange multipliers are such that $\lambda_{j}>0$ if constraint $\mathrm{j}$ is active or $\lambda_{\mathrm{j}}=0$ if constraint $\mathrm{j}$ is inactive. Differentiate (15) w.r.t. the design variables $\left(\mathbf{X}_{\mathrm{k}}\right)$ and rearrange the terms to obtain

$$
1=-\sum_{j=1}^{m} \lambda_{j}\left[\left(\frac{\partial g_{j}}{\partial X_{k}}\right) /\left(\frac{\partial z}{\partial X_{k}}\right)\right]
$$

Multiply both sides of Eq. (16) by $X_{k}$ and take the $\eta_{\text {th }}$ root and then, apply a first order binomial expansion to obtain

$$
X_{K}^{v+1}=X_{K}^{v}\left[1-\frac{1}{\eta}\left[1+\sum_{J=1}^{n} \lambda_{J}\left[\left(\frac{\partial g_{j}}{\partial X_{k}}\right) /\left(\frac{\partial z}{\partial X_{k}}\right)\right]\right.\right.
$$

Where

$\eta=$ step-size parameter that controls convergence. $v+1$ and $v$ indicate successive iterations. Consider the change $\Delta \mathrm{g}_{1}$ in the 1 th constraint due to changes $\Delta \mathrm{X}_{\mathrm{k}}$ in the design variables ie,

$$
\Delta g_{l}=g_{l}\left(X_{k}^{v}+\Delta X_{k}\right)-g_{l}\left(X_{k}^{v}\right)=\sum_{k=1}^{3} \frac{\partial g_{l}}{\partial X_{k}} \Delta X_{k}
$$

from Eqns. (17 and 18) we deduce that

$$
\Delta X_{k}=X_{k}^{v+1}-X_{k}^{v}=\frac{-X_{k}^{v}}{\eta}\left[1+\sum_{j=1}^{m} \lambda_{j}\left(\frac{\partial g_{l}}{\partial X_{k}}\right) /\left(\frac{\partial Z}{\partial X_{k}}\right)\right]
$$

We have from Eqns. (18 and 19) that

$$
\sum_{j=1}^{m} \lambda_{j} \sum_{k=1}^{3} x_{k}^{v}\left[\left(\frac{\partial g_{l}}{\partial X_{k}}\right)\left(\frac{\partial g_{j}}{\partial X_{k}}\right) /\left(\frac{\partial Z}{\partial X_{x}}\right)\right]=\eta g_{l}\left(X_{k}^{v}\right)-\sum_{k=1}^{3} X_{k}^{v} \frac{\partial g_{l}}{\partial X_{k}}(1=1, \ldots \mathrm{m})
$$

The optimization problem is solved using Eq. (17) and Eq.(20) in an iterative procedure. However the components of the gradient vector $\partial \mathrm{Z} / \partial \mathrm{X}_{\mathrm{k}}, \partial \mathrm{g}_{\mathrm{j}}, \partial \mathrm{X}_{\mathrm{k}}$ are replaced by the normalized forms.

$$
\begin{gathered}
\frac{\partial Z}{\partial X_{k}}=\|\nabla z\| \frac{\partial \bar{Z}}{\partial X_{k}} \\
\frac{\partial g_{j}}{\partial X_{k}}=\left\|\nabla g_{j}\right\| \frac{\partial \overline{g_{j}}}{\partial X_{k}}
\end{gathered}
$$

where:

$$
\|\nabla Z\|=\sqrt{(\partial Z / \partial b)^{2}+(\partial Z / \partial h)^{2}+\left(\partial Z / \partial a_{s}\right)^{2}}
$$

and

$\left\|\nabla_{g j}\right\|$ is computed in the same sense eg. 
$\left\|\nabla F_{x}\right\|=\sqrt{\left(\partial F_{x} / \partial b\right)^{2}+\left(\partial F_{x} / \partial h\right)^{2}+\left(\partial F_{x} / \partial a_{s}\right)^{2}}$

Therefore, equations (17 and 20) respectively yield to the two following equations.

$$
X_{k}^{v+1}=X_{k}^{v}\left\{1-\frac{1}{\eta}\left[1+\sum_{j=1}^{m} \Lambda_{j}\left(\frac{\partial \bar{g}_{j}}{\partial X_{k}} / \frac{\partial \bar{Z}}{\partial X_{k}}\right)\right]-\right\}
$$

and substituting from Eqns. (21 and 22) into Eq. (20), the normalized system of linear equations in terms of Lagrange variables is

$\sum_{j=1}^{m} \Lambda_{j} \sum_{k=1}^{3} X_{k}^{v}\left[\left(\frac{\partial \overline{g_{l}}}{\partial X_{k}}\right)\left(\frac{\partial \overline{g_{l}}}{\partial X_{k}}\right) /\left(\frac{\partial \bar{Z}}{\partial X_{x}}\right)\right]=\frac{\eta g_{l}\left(X_{k}^{v}\right)}{\left\|\nabla g_{l}\right\|}-\sum_{k=1}^{3} X_{k}^{v} \frac{\partial \overline{g_{l}}}{\partial X_{k}}$

where the normalized Lagrange Variables are

$\Lambda_{j}=\lambda_{j} \frac{\left\|\nabla g_{j}\right\|}{\|\nabla Z\|}$

The Gauss-Seidel technique is applied to solve Eq. (24) for the Lagrange variables $\Lambda_{\mathrm{j}}$. The Gauss-Seide1 technique involves an iterative procedure given by:

$$
\Lambda_{j}^{ \pm 1}=\frac{1}{e_{u}}\left(b_{l} \sum_{j=1}^{l-1} e_{l j} \Lambda_{j}^{=+1}-\sum_{j=l+1}^{l-1} e_{l j} \Lambda_{j}^{-}\right)
$$

noting that $\Lambda_{j}^{-}$and $\Lambda^{-+1}$ in the R.H.S. of Eq. (26) are the old and new Lagrange variables respectively where from Eq. (24)

$$
\begin{gathered}
e_{l l}=\sum_{k=1}^{3} X_{k}^{v}\left[\left(\frac{\partial \overline{g_{l}}}{\partial X_{k}}\right)\left(\frac{\partial \overline{g_{l}}}{\partial X_{k}}\right) /\left(\frac{\partial \bar{Z}}{\partial X_{k}}\right)\right] \\
e_{l j}=\sum_{k=1}^{3} X_{k}^{v}\left[\left(\frac{\partial \overline{g_{l}}}{\partial X_{k}}\right)\left(\frac{\partial \overline{g_{j}}}{\partial X_{k}}\right) /\left(\frac{\partial \bar{Z}}{\partial X_{k}}\right)\right] \\
b_{l}=\eta \frac{g_{l}\left(X_{k}^{v}\right)}{\left\|\nabla g_{l}\right\|}-\sum_{k=1}^{3} X_{k}^{v}\left(\frac{\partial \bar{g}_{l}}{\partial X_{k}}\right)
\end{gathered}
$$

\section{DESIGN OPTIMIZATION PROCEDURE}

The following arc the steps of design:

1. Set $v=0$ and adopt on initial set of design variables $X_{k}$

2. For the current $\mathrm{X}^{\mathrm{v}}{ }_{\mathrm{k}}$, establish the gradient vector $\partial \mathrm{Z} / \partial \mathrm{X}_{\mathrm{k}}$

3. For the current $X_{k}$, analyses the structure and establish the gradient vectors $\partial \mathrm{g}_{\mathrm{j}}$ $/ \partial \mathrm{X}_{\mathrm{k}}(\mathrm{j}=1$, m) for the $m$ constraints that are currently active.

4. For the current active $X_{k}{ }^{v}$; use Gauss-Seidel technique Eq.(29) to solve Eq.(24) for the set of Lagrange multipliers $\Lambda_{j}^{\mathrm{v}}$. When convergence of the Gauss- Seidel technique has occurred such that $\Lambda_{j}^{-}=\Lambda^{-+1}$ the solution of Eq. (24) has been found as $\Lambda_{\mathrm{j}}^{\mathrm{v}}=\Lambda^{-+1}{ }_{\mathrm{j}}$ 
5. For the current active $X_{k}^{v}$ and current $\Lambda_{j}^{v}$, find the new set of active design variables $\mathrm{X}_{\mathrm{k}}{ }^{\mathrm{v}+1}$ from $\mathrm{Eq}(23)$.

6. If all $\mathrm{x}_{\mathrm{k}}{ }^{v+1}=\mathrm{x}_{\mathrm{k}}{ }^{v}$ and $\Lambda_{\mathrm{j}}^{\mathrm{v}}=\Lambda^{v-1}{ }_{\mathrm{j}}$, go to step 7; otherwise set $v=v+1$ and update Eq (24). For the current xk $v$ values and return to step 4.

7. If the cost is the same for two successive design cycles, terminate with the minimum cost, otherwise set $v=0$ and return to step2.

A computer program was developed by the writer to solve the optimization problem the flow-chart of the program is given in Fig. 2.

The optimal criteria, (O.C.), is adopted herein to solve several composite girders under biaxial bending. It is shown that the O.C. provides an effective iterative optimization strategy that converges in relatively few cycles to the least cost. The convergence is achieved whether the start point is feasible or infeasible. Also, a comparison between the O.C. and the penalty function method is held to show the difference of the rate of convergence of the two methods.

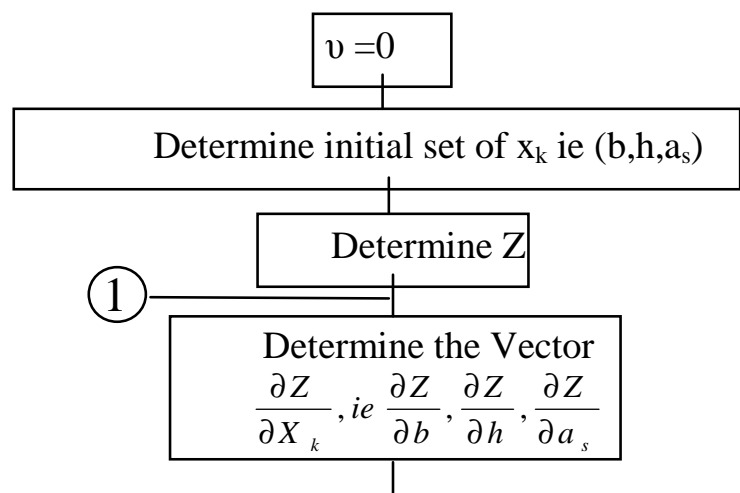

Analyze the structure and Determine

1- Nominal force $F_{z n}$ for the given internal forces $M_{y}$ and $M_{x}$

2- Nominal moment $M_{y n}$ for the given internal forces $F_{z}$ and $M_{x}$

3- Nominal moment $M_{x n}$ for the given internal forces $F_{z}$ and $M_{y}$

Add the specified increment $(\delta b)$ to the design variable (b) to obtain $(b+\delta b)$ and then determine

1- Nominal force $F_{z n}$ for the given internal forces $M_{y}$ and $M_{x}$

2- Nominal moment $M_{y n}$ for the given internal forces $F_{z}$ and $M_{x}$

3- Nominal moment $M_{x n}$ for the given internal forces $F_{z}$ and $M_{y}$

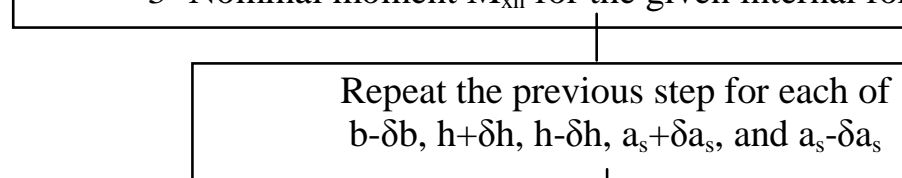

Determine the vector of $\frac{\partial g_{j}}{\partial X_{k}}$ for the constraints that are currently active ie,

$$
\frac{\partial F_{z n}}{\partial b}, \frac{\partial F_{z n}}{\partial h}, \frac{\partial F_{z n}}{\partial a_{s}} \quad \frac{\partial M_{y n}}{\partial b}, \frac{\partial M_{y n}}{\partial h}, \frac{\partial M_{y n}}{\partial a_{s}} \quad \frac{\partial M_{x n}}{\partial b}, \frac{\partial M z_{x n}}{\partial h}, \frac{\partial M_{x n}}{\partial a_{s}}
$$




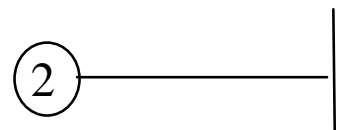

For the current active $\mathrm{X}^{0}{ }_{\mathrm{k}}$ use Gauss-Siedel to obtain the Lagrange multipliers $\Lambda_{\mathrm{j}}{ }_{\mathrm{j}}$ Eq. 24

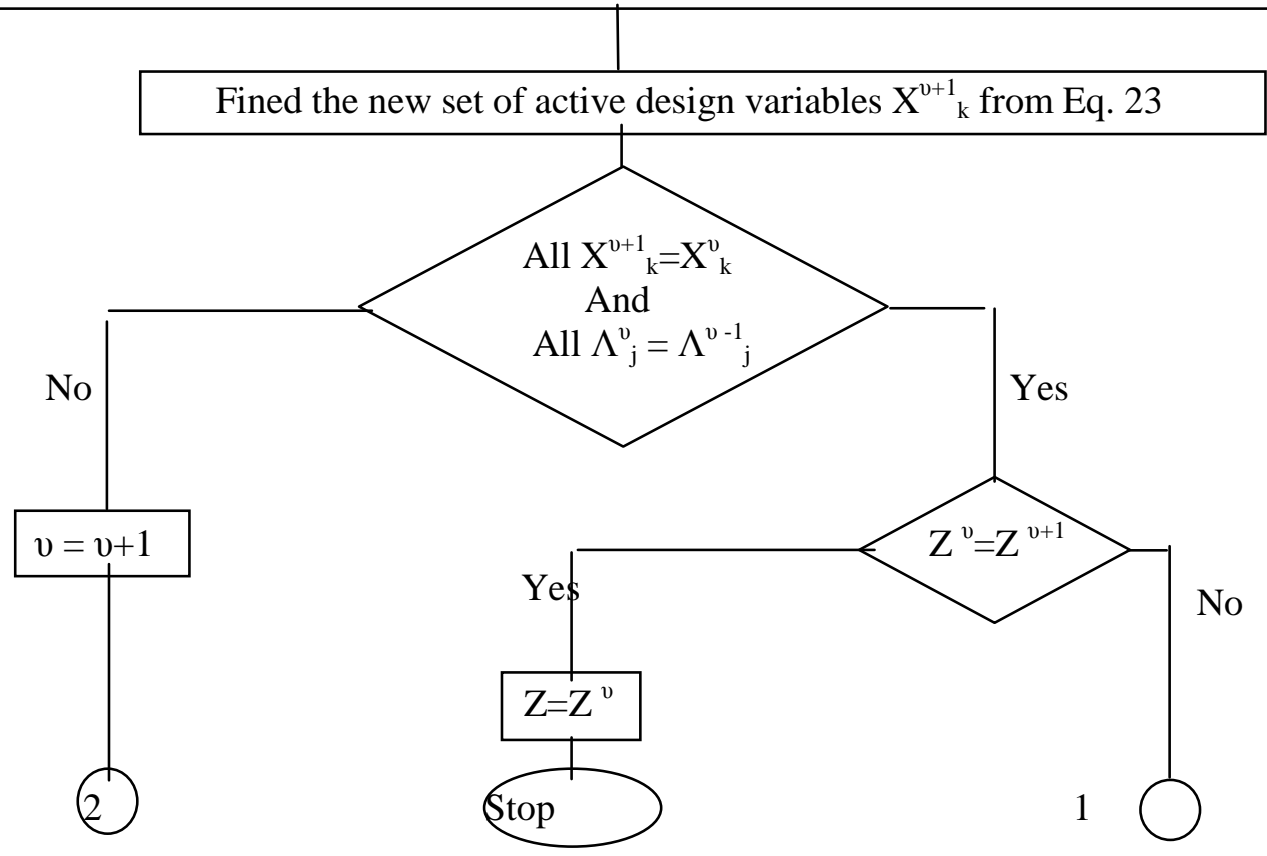

Fig. 2 Flow chart of optimization program

\section{EXAMPLES FOR COMPOSITE GIRDER SOLVED BY O.C}

\section{Composite girder 1(CG1):}

The first problem solved, herein, is a full composite girder for length and cross-section is shown in Fig. 3. The cross-section has the following properties:

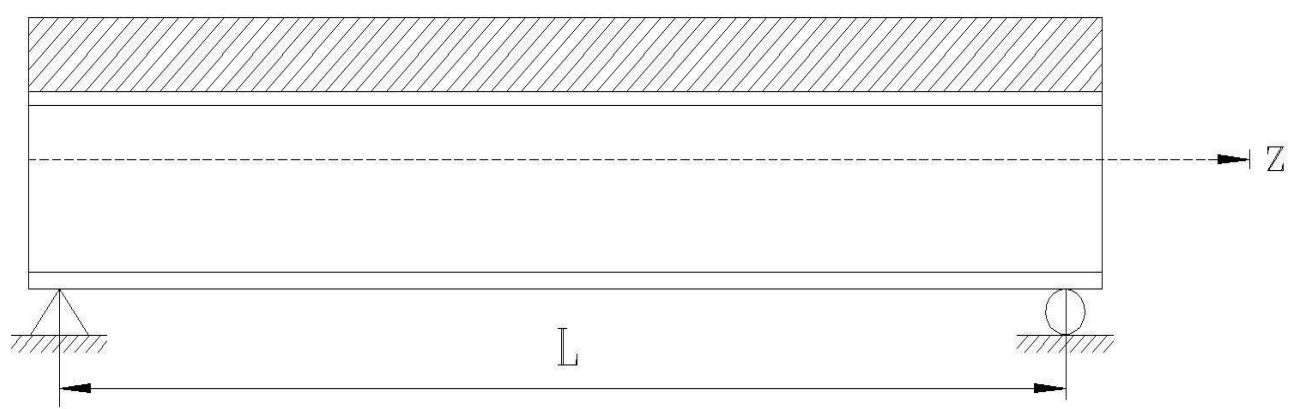

a-Elevation of Composite girder 


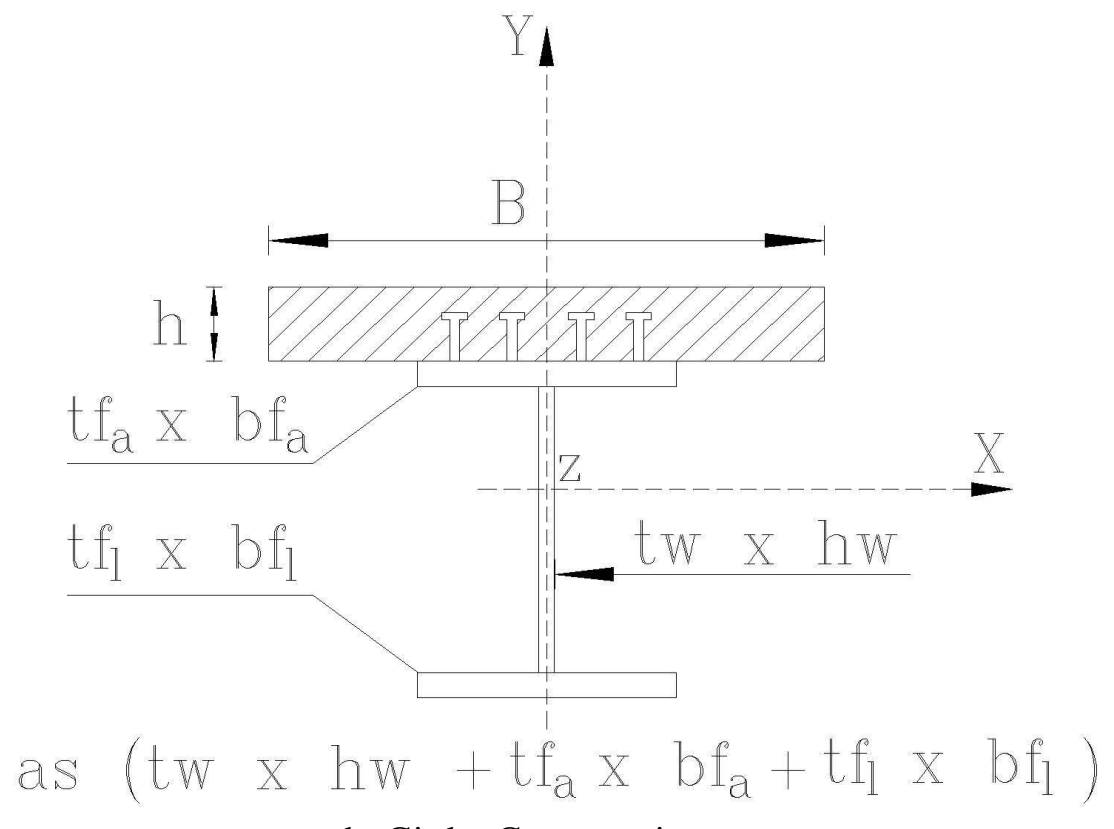

b- Girder Cross-section

Fig. 3 Composite Girder (CG1\& CG2\& CG3\& CG4\& CG5)

$\mathrm{f}_{\mathrm{sy}}=3.6 \mathrm{E} 4 \mathrm{t} / \mathrm{m}^{2}, \mathrm{f}_{\mathrm{c}}=2550 \mathrm{t} / \mathrm{m}^{2}, \mathrm{E}_{\mathrm{s}}=2.06 \mathrm{E} 7 \mathrm{t} / \mathrm{m}^{2}$.

The composite beam is subjected to the forces $\mathrm{Fz}=400 \mathrm{t}, \mathrm{M}_{\mathrm{x}}=50 \mathrm{mt}$. and $M_{y}=20 \mathrm{mt}$. The design variables are the width, height of the concrete slab $b, h$ and area of steel $a_{s}$. The design optimization problem is to find the values of the design variables such as to minimize the cost of the composite girder, accounting for the costs of concrete slab, steel and formwork while satisfying constraints given in Eqns. (2 to $5)$.

The ratio of the unit volume cost of steel to that of concrete is taken as 60 , while the ratio of unit area cost of shattering to the unit volume cost of concrete is 0.6. The design optimization problem has the following objective function, strength and sizing constraints:

Minimize $\mathrm{Z}=\left[\mathrm{b} h+(60-1) \mathrm{a}_{\mathrm{s}}+2 * 0.6(\mathrm{~b} * \mathrm{~h})\right] \mathrm{L}$

Subject to

$\mathrm{F}_{\mathrm{z}} \leq \mathrm{F}_{\mathrm{zn}}$

$\mathrm{M}_{\mathrm{x}} \leq \mathrm{M}_{\mathrm{xn}}$

$\mathrm{M}_{\mathrm{y}} \leq \mathrm{M}_{\mathrm{yn}}$

$0.80 \mathrm{~m}<\mathrm{b}<3.00 \mathrm{~m}$

$0.05 \mathrm{~m}<\mathrm{h}<0.50 \mathrm{~m}$

$20 \mathrm{~cm}^{2}<$ as $<500 \mathrm{~cm}^{2}$

Eq.(30) is the objective function, Eqns (31 to 33) are constraints on the axial 
force, moments about $\mathrm{x}$-axis and $\mathrm{y}$-axis respectively. Eqns (34 to 36) are sizing constraints on concrete slab section dimensions and steel area. The steps presented hereafter are followed to solve the problem.

1- Set $v=0$, where $v$ is the counter of iterations and start with the design variables $\mathrm{b}=1.20 \mathrm{~m}, \mathrm{~h}=0.10 \mathrm{~m}$ and $\mathrm{a}_{\mathrm{s}}=(\mathbf{0 . 8 \times 2 2 . 0 + 2 \times 1 . 0 \times 1 5 . 0})=47.60 \mathrm{~cm}^{2}$.

2- For the current $X_{k}$, where $X_{k}=\left\{b, h, a_{s}\right\}$,establish $\partial Z / \partial X_{k}$

where

$\partial \mathrm{Z} / \partial \mathrm{b}=[\mathrm{h}+2 * 0.6(\mathrm{~h})] \mathrm{L}$

$\partial \mathrm{Z} / \partial \mathrm{h}=[\mathrm{b}+2 * 0.6(\mathrm{~b})] \mathrm{L}$

$\partial \mathrm{Z} / \partial \mathrm{a}_{\mathrm{s}}=[60-1] \mathrm{L}$

3- The strength gradient $\partial \mathrm{S} / \partial \mathrm{X}_{\mathrm{k}}$ is found using the interaction diagram presented in details as follows:

The axial force capacity, $\mathrm{F}_{\mathrm{zn}}$, is computed for the current design variables (b $=1.20 \mathrm{~m}, \mathrm{~h}=0.10 \mathrm{~m}$, and $\left.\mathrm{a}_{\mathrm{s}}=47.60 \mathrm{~cm}^{2}\right\}$ by fixing $\mathrm{M}_{\mathrm{y}}=20 \mathrm{mt}$ and $\mathrm{M}_{\mathrm{x}}=50 \mathrm{mt}$ and running the computer program to give a point on the interaction diagram of the composite girder solved. Each of the other force capacities $M_{y n}$ and $M_{x n}$ are computed in the same sense. Each of $F_{z n}, M_{y n}$ and $M_{x n}$ are then computed in the six designs $\left\{b+\delta b, b-\delta b, h+\delta h, h-\delta h, a_{s}+\delta a_{s}\right.$ and $\left.a_{s}-\delta a_{s}\right\}$

The gradient vector $\partial \mathrm{g} / \partial \mathrm{X}_{\mathrm{k}}$ is then computed where

$\partial \mathrm{g} / \partial \mathbf{X}_{\mathrm{k}}=\partial \mathrm{F} / \partial \mathbf{X}_{\mathrm{k}}-\partial \mathrm{S} / \partial \mathbf{X}_{\mathrm{k}}$

The strength sensitivities $\partial \mathrm{S} / \partial \mathrm{Xk}$ is given as $\left\{\partial \mathrm{F}_{\mathrm{xn}} / \partial \mathrm{b}, \partial \mathrm{F}_{\mathrm{xn}} / \partial \mathrm{h}, \partial \mathrm{F}_{\mathrm{x}} / \partial \mathrm{a}_{\mathrm{s}}\right.$, $\partial \mathbf{M}_{\mathrm{yn}} / \partial \mathrm{b}, \partial \mathbf{M}_{\mathrm{yn}} / \partial \mathrm{h}, \partial \mathbf{M}_{\mathrm{yn}} / \partial \mathrm{a}_{\mathrm{s}}, \partial \mathbf{M}_{\mathrm{zn}} / \partial \mathrm{b}, \partial \mathbf{M}_{\mathrm{zn}} / \partial \mathrm{h}$ and $\left.\partial \mathbf{M}_{\mathrm{zn}} / \partial \mathrm{a}_{\mathrm{s}}\right\}$

where

$\frac{\partial F_{x n}}{\partial b}=\frac{F_{z n}(b+\delta b)-F_{z n}(b-\delta b)}{2 \delta b}$

and the other components are computed in the same sense.

The components of the gradient vectors $\partial \mathrm{Z} / \partial \mathrm{X}_{\mathrm{k}}$ and $\partial \mathrm{g} / \partial \mathrm{X}_{\mathrm{k}}$ are replaced by the normalized forms given in Eqns. (21 and 22) in which the increments of change $\delta b$ and $\delta$ h are taken as $0.05 \mathrm{~m}, 0.01$ respectively and the increment of change $\delta \mathrm{a}_{\mathrm{s}}$ is taken as the average between the differences of $\mathrm{a}_{\mathrm{s}}$ of the preceding and proceeding steel profiles to the steel profile specified in the iteration considered.

4- Apply Gauss-Seidel technique, Eqns. (26 to 29) to solve Eq. (24). for the normalized Lagrange variables $\Lambda_{\mathrm{j}}$.

The steps are as follows:

Knowing that, each of $l$ and $\mathrm{j}$ is the counter for the constraints corresponding to $\mathrm{F}_{\mathrm{z}}, \mathrm{M}_{\mathrm{x}}$ and $\mathrm{M}_{\mathrm{y}}$ respectively, then $\mathrm{e}_{11}$ in eq. (7.27) is computed as

$$
e_{11}=b\left(\frac{\partial \bar{F}_{z}}{\partial b} * \frac{\partial \bar{F}_{z}}{\partial b}\right) / \frac{\partial \bar{z}}{\partial b}+h\left(\frac{\partial \bar{F}_{z}}{\partial h} * \frac{\partial \bar{F}_{z}}{\partial h}\right) / \frac{\partial \bar{z}}{\partial h}+a_{s}\left(\frac{\partial \bar{F}_{z}}{\partial a_{s}} \frac{\partial \overline{F_{z}}}{\partial a_{s}}\right) / \frac{\partial \bar{z}}{\partial a_{s}}
$$

$e_{22}$ and $e_{33}$ are computed in the same sense as $e_{11}$ by replacing $F_{z}$ by $M_{x}$ for $e_{22}$ and $F_{z}$ by $\mathrm{M}_{\mathrm{y}}$ for $\mathrm{e}_{33}$.

$\mathrm{e}_{12}$ in Eq. (28) is computed as: 
$e_{12}=b\left(\frac{\partial \overline{F_{z}}}{\partial b} * \frac{\partial \overline{M_{x}}}{\partial b}\right) / \frac{\partial \bar{Z}}{\partial b}+h\left(\frac{\partial \overline{F_{z}}}{\partial h} * \frac{\partial \overline{M_{x}}}{\partial h}\right) / \frac{\partial \bar{Z}}{\partial h}+a_{s}\left(\frac{\partial \overline{F_{z}}}{\partial a_{s}} * \frac{\partial \overline{M_{x}}}{\partial a_{s}}\right) / \frac{\partial \bar{Z}}{\partial a_{s}}$

$\mathrm{e}_{13}$ and $\mathrm{e}_{23}$ are computed in the same sense as $\mathrm{e}_{12}$ but by taking the forces corresponding to 1 and $j$ in return. It is thus obvious that $e_{j}=e_{j 1}$.

$\mathrm{b}_{1}$ in Eq. (29) is computed as

$$
b_{1}=\eta^{*} \frac{\left(F_{z}-F_{z n}\right)}{\nabla F_{z}}-b\left(\frac{\partial \bar{F}_{z}}{\partial b}\right)-h\left(\frac{\partial \bar{F}_{z}}{\partial h}\right)-a_{s}\left(\frac{\partial \bar{F}_{z}}{\partial a_{s}}\right)
$$

and $b_{2}$ and $b_{3}$ are computed in the same sence as $b_{1}$, but by replacing $F_{z}$ by $M_{x}$ and $M_{y}$ respectively.

$\mathrm{Eq}$. (26) computes the normalized lagrange variables.

Set $\Lambda_{\mathrm{j}}=\left(\Lambda_{1}, \Lambda_{2}, \Lambda_{3}\right)=(0,0,0)$

And compute

$$
\begin{aligned}
& \Lambda_{1}=\frac{1}{e_{11}}\left(b_{1}-e_{12} \Lambda_{2}^{\text {old }}-e_{13} \Lambda_{3}^{\text {old }}\right) \\
& \Lambda_{2}=\frac{1}{e_{22}}\left(b_{2}-e_{11} \Lambda_{2}^{\text {new }}-e_{23} \Lambda_{3}^{\text {old }}\right) \\
& \Lambda_{3}=\frac{1}{e_{33}}\left(b_{3}-e_{3} \Lambda_{1}^{\text {new }}-e_{32} \Lambda_{2}^{\text {new }}\right)
\end{aligned}
$$

Replace the old values of $\Lambda_{\mathrm{j}}$ by the new set $\left(\Lambda_{1}, \Lambda_{2}, \Lambda_{3}\right)$ and repeat the three previous Eqns. until convergence is achieved 5.

5- Apply Eq. (23) to find the new set of design variables (b, h, $\left.a_{s}\right)$. As an example the variable $\mathrm{b}$ is computed as:

$$
b^{\text {new }}=b^{\text {old }}\left\{1-\frac{1}{\eta}\left[1+\Lambda_{1} * \frac{\partial \overline{F_{z}}}{\partial b} / \frac{\partial \bar{Z}}{\partial b}+\Lambda_{2} * \frac{\partial \overline{M_{x}}}{\partial b} / \frac{\partial \bar{Z}}{\partial b}+\Lambda_{3} * \frac{\partial \overline{M_{y}}}{\partial b} / \frac{\partial \bar{Z}}{\partial b}\right]\right\}
$$

$\mathrm{h}$ and $\mathrm{a}_{\mathrm{s}}$ are computed in the same sense as $\mathrm{b}$ but by replacing $\mathrm{b}$ by $\mathrm{h}$ and $\mathrm{a}_{\mathrm{s}}$ respectively.

The new set of variables obtained are $b=1.10 \mathrm{~m}, \mathrm{~h}=10.0 \mathrm{~cm}$ and $\mathrm{a}_{\mathrm{s}}=47.60 \mathrm{~cm}^{2}$.

Set $v=v+1$ and go to step 2. Proceed with the steps to achieve a new section. Repeat several times till convergence is achieved.

6- For the last cross-section check that the deflection is within the limits of the code. Table (1) shows the steps of convergence.

\section{Composite girders 2 to 4 (CG2 TO CG4)}

The three full composite girders, the length and cross-section are presented in tables 2 to 4 , the design parameters, and end cost given bellow.

The results of the previous examples are plotted on the Fig. 4 to 7.

From Figs. 4 to 7 , we observe that the final cost of the composite girders (CG) is less than the initial cost by a percentage ranging from $18.7 \%$ to $22.4 \%$. The equation of the cost as deduced from Figs. 4 to 7 is: 
Cost $=-\mathrm{A} \ln (\mathrm{x})+\mathrm{B}$

Where

$\mathrm{A}=$ the constant from range (3.1 to 4.6$)$;

$\mathrm{B}=$ the constant from range (11.8 to 23.9$)$.

The constants $A$ and $B$ depend on the first iteration which depends on $F_{z}, M_{x}, M_{y}, L$, $f_{s y}, f_{c}^{\prime}$.

Table 1 Convergence of Composite Girder 1 (CG1)

\begin{tabular}{|c|c|c|c|c|c|}
\hline $\begin{array}{l}\text { No. of } \\
\text { Iterations }\end{array}$ & $\begin{array}{c}\text { b } \\
(\mathrm{cm})\end{array}$ & $\begin{array}{c}\mathbf{h} \\
(\mathbf{c m})\end{array}$ & 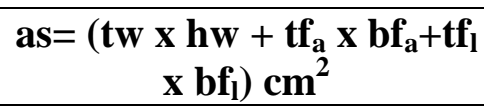 & $\begin{array}{c}\text { Stress } \\
\text { percentage }\end{array}$ & $\begin{array}{c}Z \\
\text { The cost }\end{array}$ \\
\hline 1 & 110.0 & 10.0 & $\begin{array}{c}(0.8 \times 22.0+1.0 \times 15.0 \\
+1.0 \times 15) \\
=47.60\end{array}$ & 32.80 & 10.99 \\
\hline 2 & 105 & 9.0 & $\begin{array}{c}(0.7 \times 21.0+0.9 \times 14.0 \\
+0.9 \times 14) \\
=39.90\end{array}$ & 66.90 & 10.19 \\
\hline 3 & 100.0 & 8.0 & $\begin{array}{c}(0.6 \times 20.0+0.84 \times 14.0 \\
+0.84 \times 14) \\
=35.52\end{array}$ & 85.20 & 9.51 \\
\hline 4 & 100.0 & 7.0 & $\begin{array}{c}(0.58 \times 19.12+0.78 \times 13.38+0.78 \\
\times 13.38) \\
=31.96\end{array}$ & 97.00 & 9.26 \\
\hline
\end{tabular}

$\mathrm{F}_{\mathrm{z}}=200 \mathrm{t}, \mathrm{M}_{\mathrm{x}}=25.0 \mathrm{mt}, \mathrm{M}_{\mathrm{y}}=5.0 \mathrm{mt}, \mathrm{L}=6.0 \mathrm{~m}$, $\mathrm{f}_{\mathrm{sy}}=36000 \mathrm{t} / \mathrm{m}^{2}, \mathrm{f}_{\mathrm{c}}=2550 \mathrm{t} / \mathrm{m}^{2}$

Table 2 Convergence of Composite Girder 2 (CG2)

\begin{tabular}{|c|c|c|c|c|c|}
\hline $\begin{array}{l}\text { No. of } \\
\text { Iterations }\end{array}$ & $\begin{array}{c}\text { b } \\
(\mathbf{c m})\end{array}$ & $\begin{array}{c}\text { h } \\
(\mathbf{c m})\end{array}$ & $\begin{array}{c}a s=\left(t w \times h w+t f_{a} x\right. \\
\left.b f_{a}+t f_{l} \times b f_{l}\right) \\
c m^{2}\end{array}$ & $\begin{array}{c}\text { Stress } \\
\text { percentage }\end{array}$ & $\begin{array}{c}Z \\
\text { The cost }\end{array}$ \\
\hline 1 & 190.0 & 18.0 & $\begin{array}{c}(1.2 \times 65.0+1.8 \times 28.0 \\
+1.8 \times 28.0 \\
=178.80\end{array}$ & 34.30 & 46.72 \\
\hline 2 & 185.0 & 16.0 & $\begin{array}{c}(1.1 \times 63.0+1.7 \times 26.0 \\
+1.7 \times 26.0 \\
=157.70\end{array}$ & 49.10 & 43.66 \\
\hline 3 & 180.0 & 15.0 & $\begin{array}{c}(1.0 \times 60.0+1.6 \times 24.0 \\
+1.6 \times 24.0 \\
=136.80\end{array}$ & 67.10 & 41.01 \\
\hline 4 & 175.0 & 14.0 & $\begin{array}{c}(0.96 \times 57.0+1.5 \times 23.44+1 \\
.5 \times 23.44 \\
=125.04\end{array}$ & 94.20 & 39.01 \\
\hline
\end{tabular}

$\mathrm{F}_{\mathrm{z}}=500 \mathrm{t}, \mathrm{M}_{\mathrm{x}}=50.0 \mathrm{mt}, \mathrm{M}_{\mathrm{y}}=12.5 \mathrm{mt}, \mathrm{L}=12.0 \mathrm{~m}$,

$\mathrm{f}_{\mathrm{sy}}=24000 \mathrm{t} / \mathrm{m}^{2}, \mathrm{f}_{\mathrm{c}}^{\prime}=0.85 * 4000 \mathrm{t} / \mathrm{m}^{2}$ 
Table 3 Convergence of Composite Girder 3 (CG3)

\begin{tabular}{|c|c|c|c|c|c|}
\hline $\begin{array}{c}\text { No. of } \\
\text { Iterations }\end{array}$ & $\begin{array}{c}\mathrm{b} \\
(\mathrm{cm})\end{array}$ & $\begin{array}{c}\text { h } \\
(\mathbf{c m})\end{array}$ & $\begin{array}{c}\text { as }=\left(\mathrm{tw} \times \mathrm{hw}+\mathrm{tf}_{\mathrm{a}} \times\right. \\
\left.\mathbf{b f}_{\mathrm{a}}+\mathrm{tf}_{\mathrm{l}} \times \mathrm{bf}_{\mathrm{l}}\right) \mathrm{cm}^{2}\end{array}$ & $\begin{array}{c}\text { Stress } \\
\text { percentage }\end{array}$ & $\begin{array}{c}\mathrm{Z} \\
\text { The cost }\end{array}$ \\
\hline 1 & 245 & 24 & $\begin{array}{c}(1.8 \times 170.0+2.5 \times 35.0 \\
+3.5 \times 50.0 \\
=568.50\end{array}$ & 31.70 & 179.25 \\
\hline 2 & 235 & 23 & $\begin{array}{c}(1.7 \times 165.0+2.3 \times 32.0 \\
+3.2 \times 48.0 \\
=507.70\end{array}$ & 52.34 & 165.80 \\
\hline 3 & 230 & 22 & $\begin{array}{c}(1.6 \times 160.0+2.1 \times 32.0 \\
+3.0 \times 46.0 \\
=461.2\end{array}$ & 69.74 & 156.28 \\
\hline 4 & 225 & 20 & $\begin{array}{c}(1.5 \times 150.0+2.0 \times 30.0 \\
+3.0 \times 45.0 \\
=420.0\end{array}$ & 98.96 & 146.70 \\
\hline
\end{tabular}

$$
\begin{gathered}
\mathrm{F}_{\mathrm{z}}=400 \mathrm{t}, \mathrm{M}_{\mathrm{x}}=105.0 \mathrm{mt}, \mathrm{M}_{\mathrm{y}}=15 \mathrm{mt}, \mathrm{L}=25.0 \mathrm{~m}, \\
\mathrm{f}_{\mathrm{sy}}=24000 \mathrm{t} / \mathrm{m}^{2}, \mathrm{f}_{\mathrm{c}}^{\prime}=0.85^{*} 3000 \mathrm{t} / \mathrm{m}^{2}
\end{gathered}
$$

\begin{tabular}{|c|c|c|c|c|c|}
\hline $\begin{array}{l}\text { No. of } \\
\text { Iterations }\end{array}$ & $\begin{array}{c}\mathrm{b} \\
(\mathrm{cm})\end{array}$ & $\begin{array}{c}\mathbf{h} \\
(\mathbf{c m})\end{array}$ & 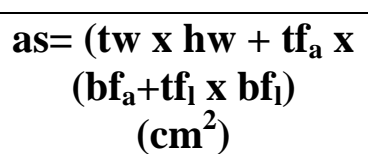 & $\begin{array}{c}\text { Stress } \\
\text { percentage }\end{array}$ & $\begin{array}{c}Z \\
\text { The cost }\end{array}$ \\
\hline 1 & 230.0 & 28.0 & $\begin{array}{c}(1.4 \times 225.0+2.0 \times 30.0 \\
+5.5 \times 45.0 \\
=622.50\end{array}$ & 44.1 & 266.86 \\
\hline 2 & 220.0 & 26.0 & $\begin{array}{c}(1.3 \times 220.0+1.8 \times 28.0 \\
+5.3 \times 42.0 \\
=559.00\end{array}$ & 73.4 & 245.60 \\
\hline 3 & 210.0 & 24.0 & $\begin{array}{c}(1.2 \times 215.0+1.6 \times 26.0 \\
+5.1 \times 40.0 \\
=503.60\end{array}$ & 88.0 & 226.20 \\
\hline 4 & 205.0 & 23.0 & $\begin{array}{c}(1.2 \times 212.0+1.5 \times 27.5 \\
+5.0 \times 37.50 \\
=483.15\end{array}$ & 98.1 & 218.09 \\
\hline
\end{tabular}

Table 4 Convergence of Composite Girder 4 (CG4)

$$
\begin{gathered}
\mathrm{F}_{\mathrm{z}}=600 \mathrm{t}, \mathrm{M}_{\mathrm{x}}=320.0 \mathrm{mt}, \mathrm{M}_{\mathrm{y}}=70 \mathrm{mt}, \mathrm{L}=36.0 \mathrm{~m}, \\
\mathrm{f}_{\mathrm{sy}}=36000 \mathrm{t} / \mathrm{m}^{2}, \mathrm{f}_{\mathrm{c}}^{\prime}=0.85^{*} 3000 \mathrm{t} / \mathrm{m}^{2}
\end{gathered}
$$




\section{CONCLUSION}

There is a reliable analytical solution for the problem of optimization for biaxial full composite girders.

A computer program is now available to give a quick and accurate solution of the optimization for biaxial full composite girders cross-sections.

The stress percentage in concrete slab, and steel girder increase when increase the iteration. At iteration number four the stress percentage reach to more than $95 \%$.

The O.C. is applied to achieve the composite girder reduces the cost by $18.7 \%$ to $22.4 \%$.

We recommend by much research in these fields, taking into account the effect of slipping and uplift between the concrete slab and steel girder.

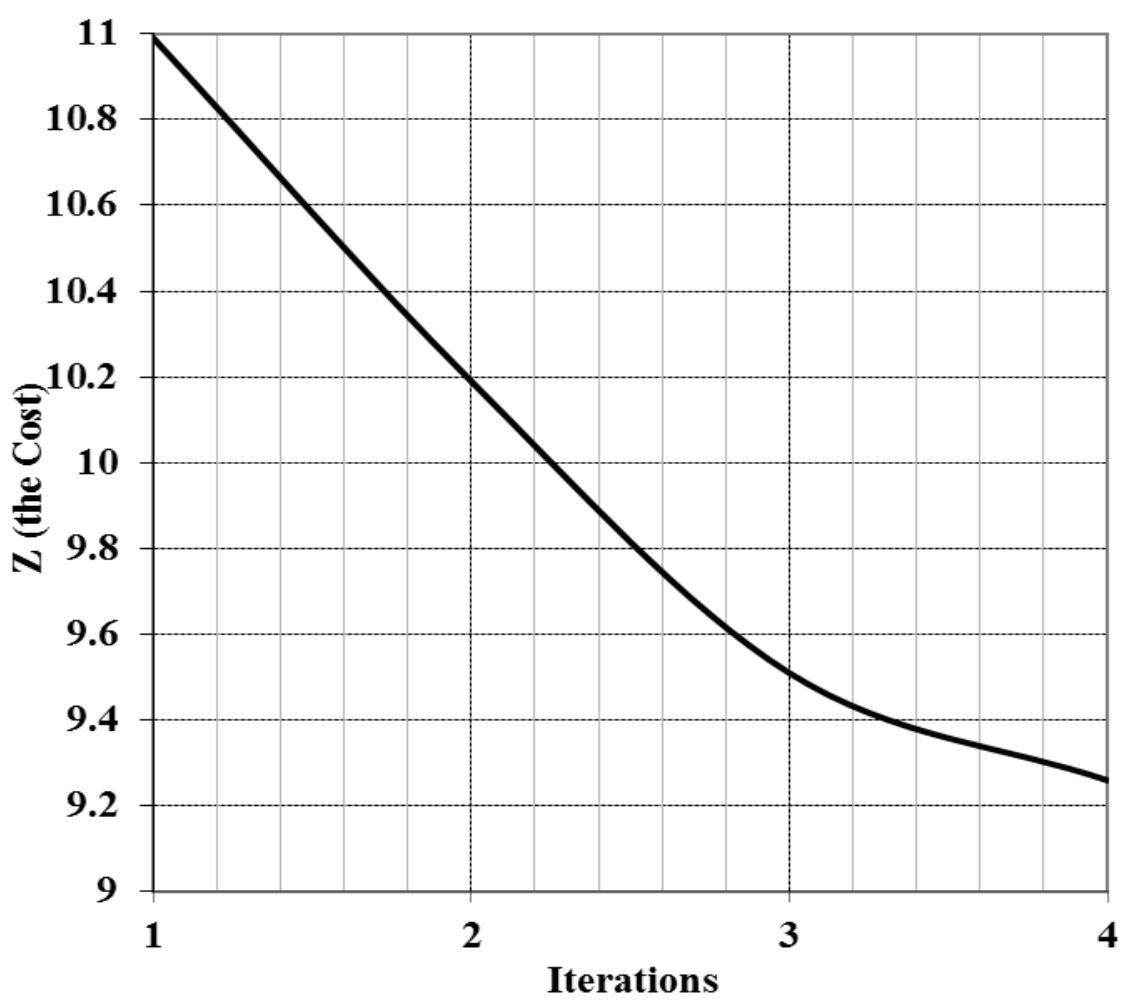

Fig. 4 The Cost Iterations for CG 1 


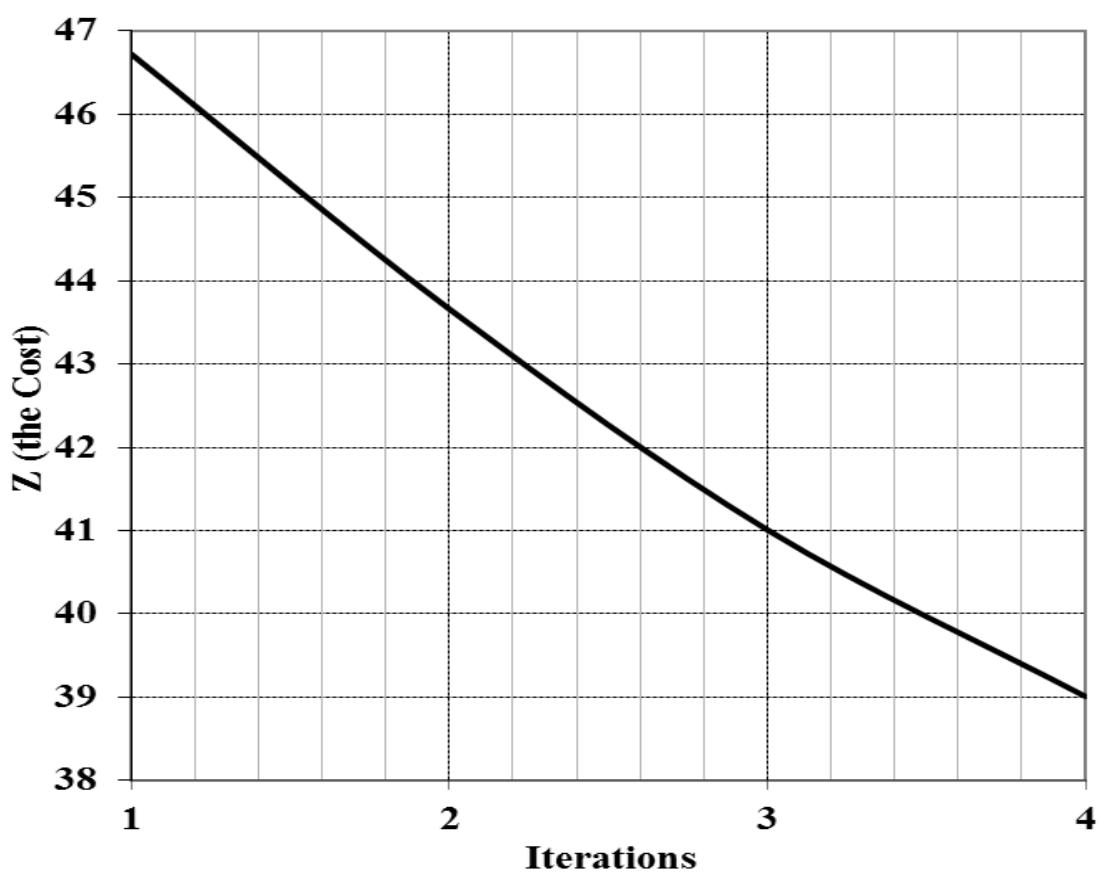

Fig. 5 The Cost Iterations for CG 2

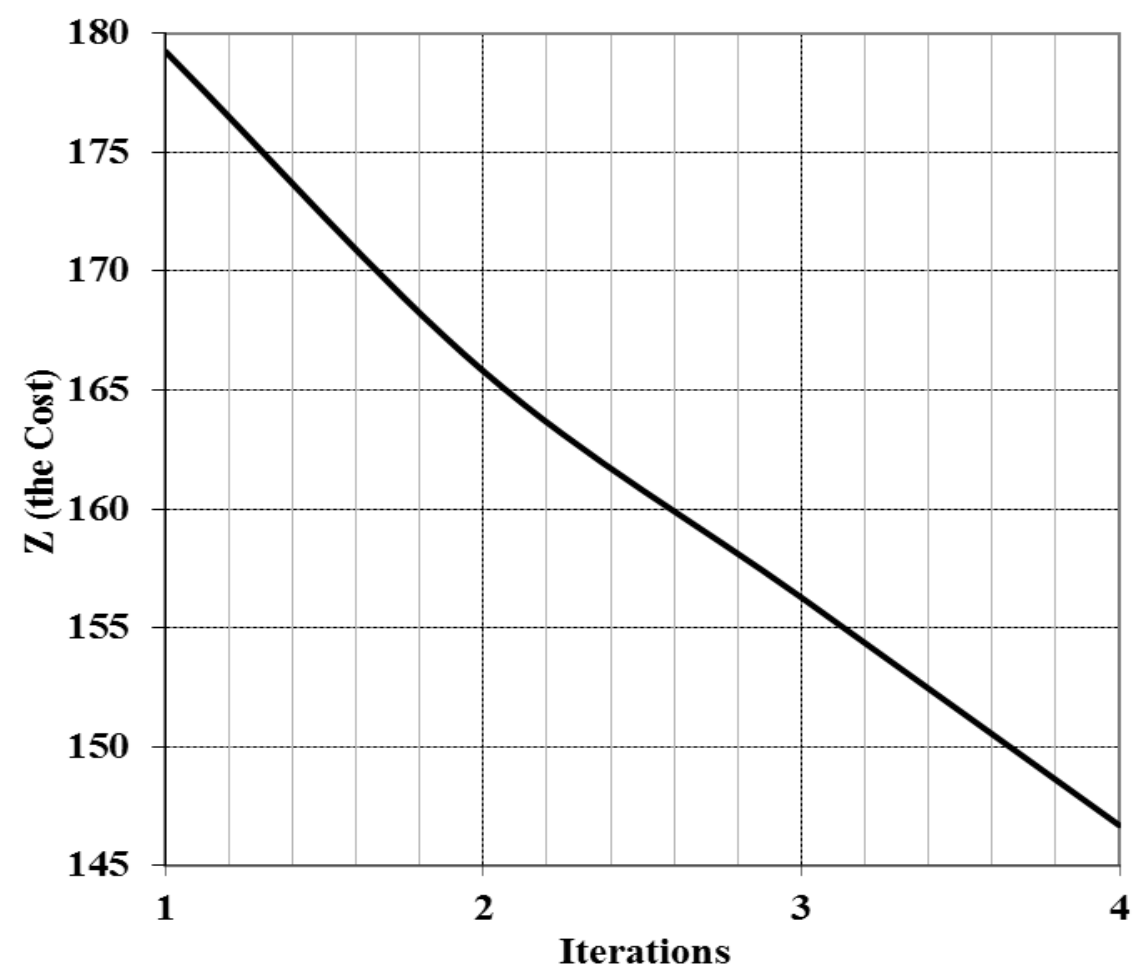

Fig. 6 The Cost Iterations for CG 3 


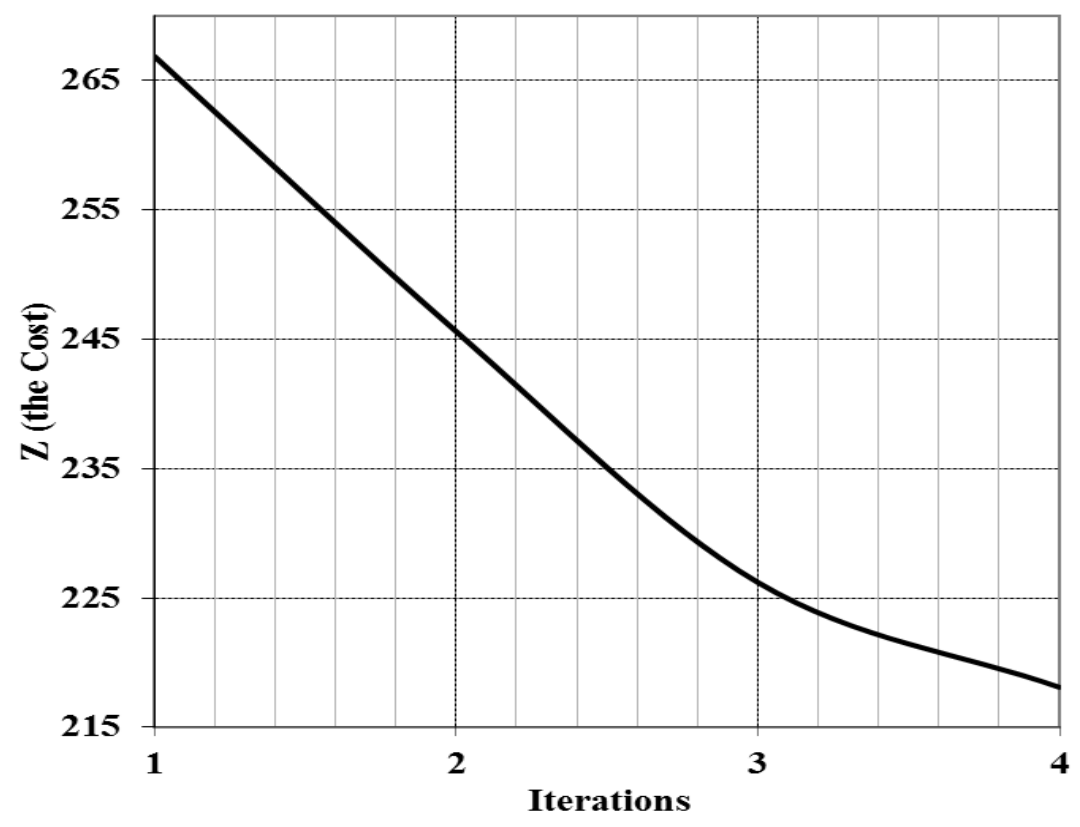

Fig. 7 The Cost Iterations for CG4

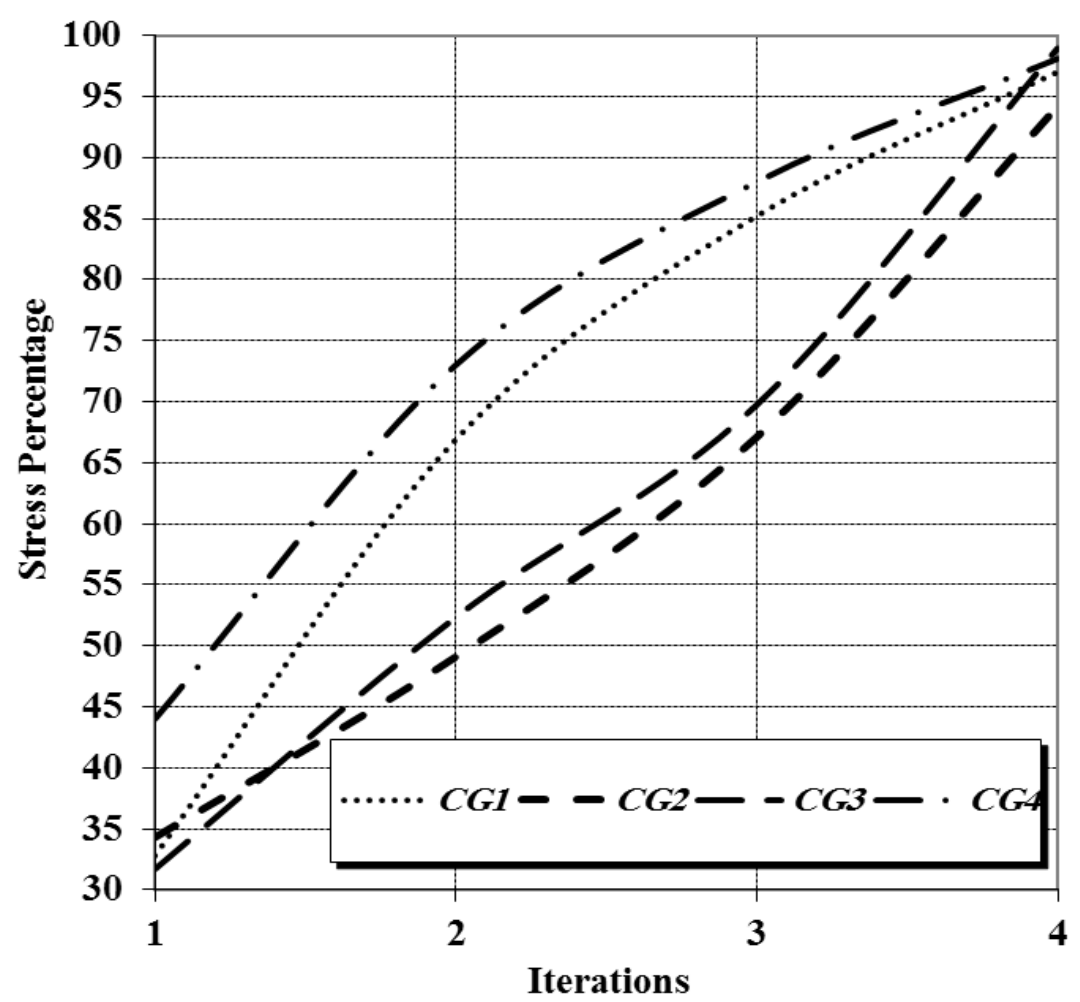

Fig. 8 Stress Percentage Iteration (CG1\& CG2\& CG3\& CG4) 


\section{REFERENCES}

1- $\quad$ "Building Code Requirements for Reinforced Concrete", ACI 318-71, American Concrete Institute.

2- Cheng-Koon Choi and Hyo-Gyoung Kwak, Optimum RC Member Design with Predetermined Discrete sections "Journal of Structural Engineering Vol. 6 No. 10, Oct. 1990, ASC pp. 2634-2655.

3- Chou. I. "Optimum reinforced concrete I-beam sections" J. of Structural Engineering ASCE Vol. 103 No. 8, 1977, pp. 1605-1617.

4- Chun-Man Chan "Optimal lateral stiffness design of tall buildings of mixed steel and concrete" the structural Design of tall buildings Vol. 10, Issue 3, July 2001, PP. 155-177.

5- Chun-Man Chan and Qian Wang "Non-linear stiffness design optimization of tall reinforced concrete buildings under service loads" J. structure Eng., Vol. 132, Issue 6, June 2006, PP. 978-990.

6- D. Val F. Bljugar and D. Yankeleusky, "Optimization problem solution in reliability analysis of Reinforced Concrete Structures", Computer and structures, Vol. 60 No. 3, 1996 pp. 351-355.

7- EL-SHAER Mohamed A. A. "ANALYSIS OF COMPOSITE GIRDERS" ph. D. thesis, Ain Shams University, Cairo, Egypt (1997).

8- E.A. Sadek, "Optimization of Structures Having General crosssection Relationships using an Optimality Criterion Method" Computers and Structures, Vol. 43, No. 5, 1992, pp. 959-969.

9- Friel 1. 1. "Optimal singly reinforced concrete section" ACI J. Proc. Vol. 71 No. 11, 1974, pp. 556-558.

10- Gang Gary Wang and Cheng-Tzu Thomas Hsu, "Computer Biaxial LoadDeflection Behavior of RC Columns", Journal of Structural Engineering ASCE, Vol. 118, No. 9, Paper No. 1357, Sep 1992, pp. 2590-2609.

11- Hajek P. and Frangopol D.M. "Optimum design of shear wall systems" Comp. Struct. Vol. 38, No. 2, 1991 pp. 171-184.

12- Hamid Moharrami and Douald E. Grierson, "Computer- Automated Design Of Reinforced Concrete Frameworks" Journal of Structural Engineering ASCE, Vol. 119, No. 9, Paper No. , July 1993, ASCE, pp. 2036-2059.

13- Kanagasundaram S. and Karihaloo B. L. "minimum cost design of reinforced concrete structures" Struct. Optim. Vol. 2, No. 3, 1991, pp. 173-184.

14- Yasir I. Musa, and Manuel A. Diaz, M. "Design Optimization of Composite Steel Box Girder in Flexure", ASCE, Practice Periodical on Structural Design and Construction, Vol. 12, No. 3, pp. 146-152, August 2007.

15- Multi Science Publishing, "Optimum Design of Reinforced Concrete Beams Using Polynomial Optimization Technic, Journal of Advances in Structural Engineering, pp. 67-79, July 29, 2009.

16- Shan Suo Zheng, Huan Juan Lou, Lei Li, Zhi Qiang Li, Wei Wang, "Optimization Design of Steel-Concrete Composite Beams Considering BondSlip Effect", Advanced Materials Research (Volumes 243 - 249), Advances in Civil Engineering and Architecture, pp. 379-382, May, 2011. 


\section{التصميم الاقتصادي للكمرات المركبة المعرضة لعزوم مزدوجة}

تقدم هذة المقالة طربقة فعالة مبنية علي الحاسب الالي لتصمبم الكمرات المركبة تحت تأثنر الانحاء الثنائي باستخدام طريقة المعيار الأمثل (Optimal Criteria ) وقد اخذ عرض وسمك القطاع الخرسانى للبلاطة الخرسانية المسلحة وقطاع الحديد كمتغيرات التصميم. وقد تم استتناج حدود المقاومة اللازمة للتصميم باستخدام طريقة العناصر المحددة. والطريقة المذكورة تقوم بحساب الكمرات المركبة آخذة في الاعتبار السلوك اللاخطي للمادة نتيجة التغير في منحنيات الإجهاد-الانفعال لكل من الخرسانة والحديد، وكذلك السلوك اللاخطي هندسيا نتيجة التغير في مسار الكمرة المركبة أثتاء الانبعاج. ويعتمد الاستتناج علي استخدام طريقة الثغل التخيلي. وقد طبقت طريقة المعيار الأمثل للوصول لاقل نكلفة للخرسانة والحديد والثدات الي الحد الادني وقد نم تطبيق الطريقة المذكورة علي اربعة كمرات مركبة.

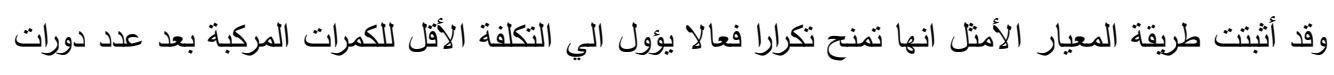
قلبلة نسبيا. والطريقة غير مرتبطة بالتصميم الإفتراضي الأول للكمرة المركبة بل تؤول إنسيابيا للتصميم النهائي للكمرة بتوافق مع إثتراطات التصميم. 